\title{
Diurnal Variation in Grapevine Water Stress as a Function of Changing Soil Water Status and Meteorological Conditions
}

\author{
J.L. van Zyl \\ Viticultural and Oenological Research Institute, Private Bag X5026, 7600 Stellenbosch, Republic of South Africa.
}

Extracted from a Ph.D. (Agric.) thesis presented to the University of Stellenbosch, 1984.

Promoter: Prof J.H. Visser

The assistance of the Soil Science Staff of the VORI is gratefully acknowledged.

Submitted for publication: August 1987

Accepted for publication: October 1987

Keywords: grapevine water stress, leaf water potential, stomatal resistance, photosynthesis

\begin{abstract}
The response of the grapevine cultivar Colombar to three irrigation treatments viz., (1) a well-watered control (2) soil water depletion to $25 \%$ plant available water (PAW) and (3) wetting of only the upper $50 \%$ of the root zone, was investigated during the ripening stage. Diurnal fluctuations in leaf water potential (LWP), stomatal resistance (Rs) and photosynthetic activity (PA) were determined weekly and relationships with meteorological factors calculated.

Water potential gradients existed between sunlit leaves, shaded leaves, bunches and soil. It is suggested that this is a driving force which creates water movement from bunches to leaves during daytime and from soil to bunches at night, thus explaining increased water use of vines with increased crop level. Diurnal changes in LWP and PA were best correlated with leaf temperature $(r=0,95)$ and photosynthetic active radiation $(r=0,74)$ respectively. During daytime, stomata remained open until a threshold leaf water potential of $-1600 \mathrm{kPa}$ was reached.

All plant parameters responded to increased water stress due to soil water depletion, but vines subjected to a reduction in the depth of wetting, showed no stress throughout the experiment. Pre-dawn LWP was the most sensitive indicator of the onset of water stress which occurred at a soil water potential (SWP) of $-64 \mathrm{kPa}$ and a corresponding $42 \%$ PAW in the soil. Pre-dawn LWP correlated highly with SWP $(r=0,95)$ and soil water content $(r=0,89)$.
\end{abstract}

The soil-water-plant-atmosphere continuum can be described as a stream flowing from a source of limited capacity and variable potential, the atmosphere (Hillel, 1971). Many variables affect this complicated continuum, necessitating a wide and comprehensive research approach when plant water relations are studied.

Transient plant water deficits develop during the day due to water losses which exceed water uptake, but generally have no lasting effect. However, water stress of longer duration as a result of decreasing soil water content is of greater importance to viticulture. Such long term deficits commence as described above, but as the soil water potential gradually decreases, plants are eventually unable to recover at night. Therefore the soil water potential sets the level of recovery at night (Slatyer, 1967; Begg \& Turner, 1976). For practical viticulture it is of the utmost importance to detect the onset of water stress as early as possible before the water potential and turgor decrease to a level that interferes with normal plant functioning.

Morphological responses to water stress are often associated with more sensitive underlying physiological processes which should therefore be ideal indicators of the onset of plant water stress. However, each plant organ and physiological process may respond differently to water stress (Hsiao, 1973). The use of plant physiological parameters of water stress is complicated by the fact that plants, including vines, differ in sensitivity towards water stress during different stages of development (Kasimatis, 1967; Begg \& Turner, 1976; Van Zyl \& Weber, 1977).

Plant water potential has gained wide acceptance as a fundamental measure of plant water status (Kramer, 1983) and has been applied in viticultural research (Smart \& Coombe, 1983). Shortly before dawn, leaf water potential approaches equilibrium with soil water potential and reaches a maximum daily value. After dawn, leaf water potential decreases rapidly to attain a minimum value after midday followed by a gradual recovery during the late afternoon and night (Smart \& Coombe, 1983). In using water potential reduction as an indicator of water stress, an absence of osmotic adjustment to the stress is assumed (Hsiao et al., 1976).

Stomatal opening is affected by water deficits and can be used as an indicator of plant water stress, although it is recognized that environmental factors such as light, $\mathrm{CO}_{2}$ and temperature also affect stomatal behaviour (Kramer, 1983). Stomatal opening, transpiration and photosynthesis often decrease concomitantly in plants subjected to increasing water stress. However, there is evidence that water stress not only results in a decline in $\mathrm{CO}_{2}$ uptake due to closure of stomata, but can cause inhibition of $\mathrm{CO}_{2}$ fixation (Kramer, 1983). Photosynthetic rate reaches a maximum at low water stress, declines with increasing stress and recovers on rewatering (Hofäcker, 1977; Smart \& Coombe, 1983).

Against the above background, an investigation was conducted to determine the onset of vine water stress using some physiological plant parameters and to establish their interrelationships and interactions with environmental conditions during diurnal cycles as well as during soil drying over the longer term.

\section{MATERIALS AND METHODS}

The investigation was conducted in an irrigation trial at Robertson in the Breede River Valley with Vitis vinifera L. cv. Colombar grafted on 99R rootstock. This trial comprised recharging of soil water from specified levels to field water capacity (FC), water stress applied at different phenological stages as well as the evaluation of the few major irrigation systems used in viticul- 
ture (Van Zyl, 1984a). Thrice weekly, soil water content (SWC) and soil water potential (SWP) were monitored with the aid of soil samples and tensiometers respectively, within the $0-250 \mathrm{~mm}, 250-500 \mathrm{~mm}, 500$ $750 \mathrm{~mm}$ and $750-1000 \mathrm{~mm}$ depth layers of the different treatment plots. A standard weather station close by, supplied meteorological data. Only a few selected treatment plots were included in the investigation reported on in this publication.

\section{Plant water potentials:}

In a preliminary study the diurnal fluctuations of the water potential of whole bunches, surilit leaves and shaded leaves were determined by the pressure chamber technique (Scholander et al., 1965) during the ripening stages of two seasons. Two treatments namely, $\mathrm{T} 1$ and $\mathrm{T} 4$ which respectively comprised a $25 \%$ and a $90 \%$ soil water regime throughout the season, were included in this investigation.

\section{Drying cycle experiment:}

In addition to the above-mentioned study, several parameters of plant water stress were determined on vines of three plots during ripening, which normally commenced in mid January and ended with harvesting at the end of March. This series of measurements started on $14 / 1 / 82$, two days after the soil water of the selected treatment plots was replenished to FC by irrigation and continued until 24/3/82 (a day before harvesting). The three treatments represented three soil water regimes viz.:

- T4: $90 \%$ soil water regime throughout the season ("wet" Treatment)

- T8: $25 \%$ soil water regime during the ripening stage ("dry" treatment). Plots belonging to this treatment were irrigated on $12 / 1 / 82$ and thereafter only on 12/3/82, 13 days before harvesting.

- T9: Weekly irrigations to maintain a $70 \%$ soil water regime in the $0-500 \mathrm{~mm}$ soil depth from véraison to harvesting. The subsoil $(500-1000 \mathrm{~mm})$ was allowed to dry out during this time.

Plant physiological measurements: Five test vines per treatment were selected visually and fully matured leaves on the upper third of fruit bearing shoots were used. Measurements were done on fully sunlit leaves, although shaded leaves were also included on T4 and T8 plots for the purpose of comparing leaf positions.

Measurement dates were as follows: 14/1/82, 20/1/82, 28/1/82, 4/2/82, 16/2/82,8/3/82 and 24/3/82. Each of these days started with the determination of pre-dawn leaf water potentials $\left(L W P_{p}\right)$ in a Scholander pressure chamber (Scholander et al., 1965). Thereafter sets of determinations were carried out five times during the course of the day viz., at approximately $08 \mathrm{~h} 00,10 \mathrm{~h} 00$, $12 \mathrm{~h} 00,14 \mathrm{~h} 00$ and $17 \mathrm{~h} 00$. The preliminary studies in the same vineyard, prior to this investigation, proved these times adequate to give a representative picture of diurnal changes in the parameters of plant water stress under discussion. Each set of determinations was completed in approximately 45 minutes in order to minimize the effect of changing environmental conditions. After selection of a representative leaf, stomatal resistance (Rs) was measured with an automatic diffusion porometer. Leaf temperature was recorded simultane- ously by a thermistor installed in the sensor head of the porometer. Photosynthetic active radiation (PAR) was determined with a portable radiometer by holding the quantum sensor perpendicular to the leaf blade. Following the measurement of PAR, total photosynthetic activity was determined on the same leaf using the method of Shimshi (1969).

Data Processing: A standard two-way analysis of variance was applied to the data sets in order to compare water regime treatments with regard to the different plant parameters. Additionally a stepwise regression programme (BMDP/2R) was applied to quantify relations among soil water status, meteorological factors and plant parameters of water stress. Data depicting diurnal variation were analysed separately from those demonstrating changes over the longer term (January to March). In the latter case only data at the time of daily maximum stress, i.e. between $14 \mathrm{~h} 00$ $15 \mathrm{~h} 00$, were used. However, LWP was also included because this parameter is generally not much affected by climatological conditions and should in theory only reflect soil water status.

To explain diurnal changes in plant parameters, the following variables were used as input:

$\begin{array}{ll}\text { Relative Humidity } & =\operatorname{RH}(\%) \\ \text { Wind Speed } & =\operatorname{Wind}\left(\mathrm{km} \mathrm{h}^{-1}\right) \\ \text { Photosynthetic Active Radiation } & =\operatorname{PAR}\left(\mu \mathrm{E} \mathrm{m}{ }^{-2} \mathrm{~s}^{-1}\right) \\ \text { Leaf Temperature } & =\mathrm{T} l\left({ }^{\circ} \mathrm{C}\right) \\ \text { Leaf Water Potential } & =\mathrm{LWP}(\mathrm{kPa}) \\ \text { Stomatal Resistance } & =\operatorname{Rs}\left(\mathrm{s} \mathrm{cm}^{-1}\right)\end{array}$

Variables used as input to determine relationships during the drying cycle of treatment T8 were as follows:

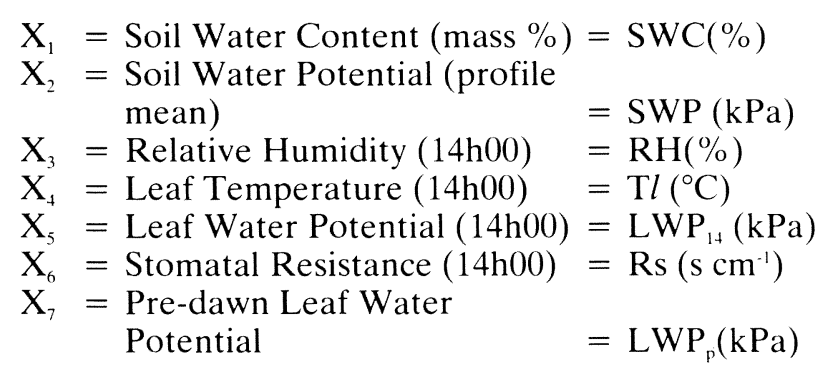

\section{RESULTS AND DISCUSSION}

\section{Leaf versus bunch water potentials:}

All plant parameters of water stress measured during the investigation displayed a large diurnal variation. The daily changes in water potential of sunlit leaves, shaded leaves and whole bunches for vines at a high soil water regime ( $\mathrm{T} 4=90 \%$ regime) are depicted in Fig. 1 and those for stressed vines ( $\mathrm{T} 1=25 \%$ regime) in Fig. 2 . These daily patterns, typical of vine water potentials determined on other days and in other seasons as well, clearly showed that the water potential of sunlit leaves was significantly lower than that of shaded leaves during the middle part of the day (10h00-16h00). This fact was further illustrated by comparing sunlit and shaded leaves in the drying cycle experiment, which yielded an average LWP of $-1282 \mathrm{kPa}$ for sunlit leaves and -1026 $\mathrm{kPa}$ for shaded leaves ( $\mathrm{D}$-value $=5,1 \mathrm{kPa}$ ) during day time. 


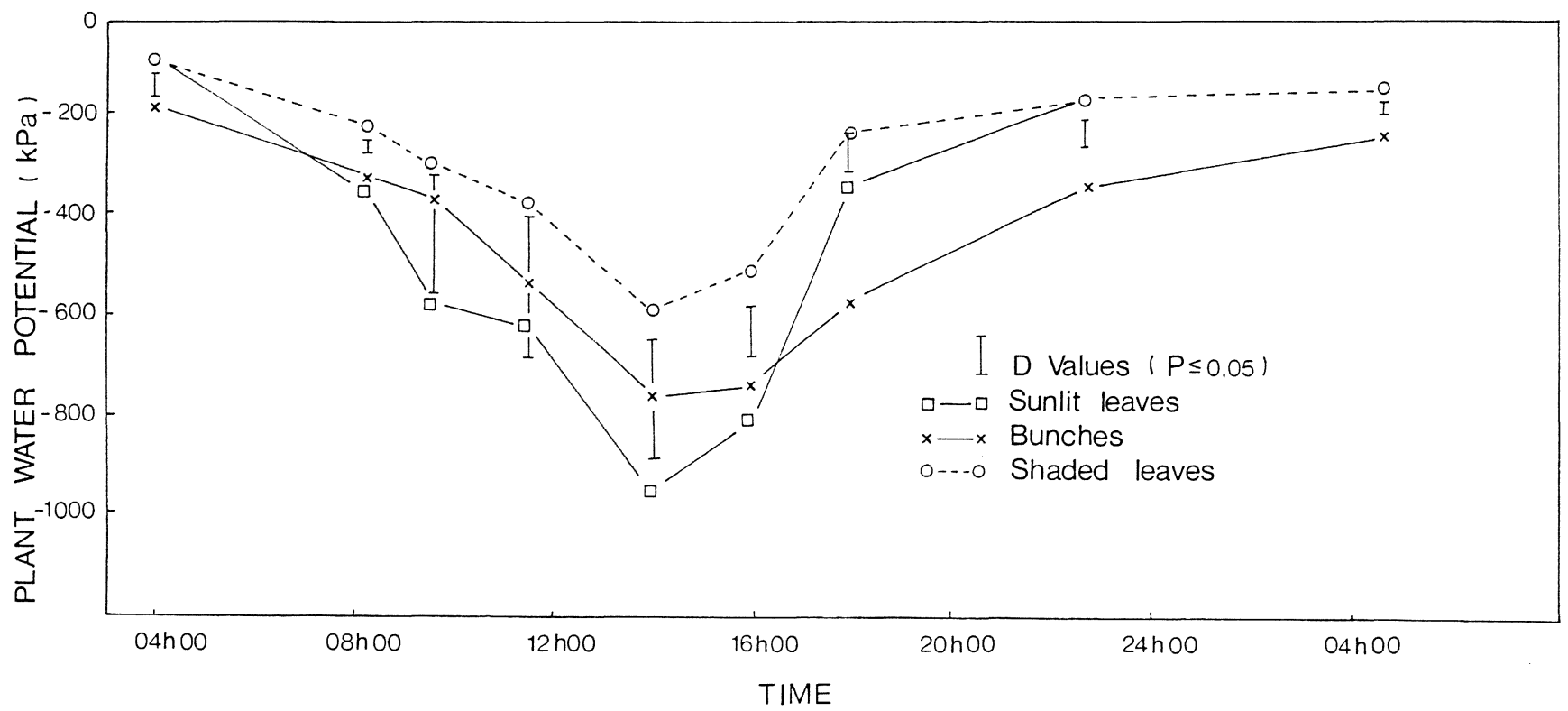

FIG. 1

Daily variation (6/1/82) in the water potential of leaves and bunches of vines at a $90 \%$ soil water regime (T4).

The water potential of bunches was lower than that of leaves during the pre-dawn period (Fig. $1 \& 2$ ). However, LWP, especially that of sunlit leaves, decreased much more rapidly in the morning and also increased at a faster rate in the afternoon than bunch water potential. Bunches normally reached their minimum water potential later in the day than the leaves (all data not shown). It was also noticeable that $\mathrm{LWP}_{\mathrm{p}}$, assumed to be in equilibrium with the soil water potential, was always, even on wet control plots such as T4 (Fig. 1), lower than the water potential in the soil (SWP

\section{$=-5 \mathrm{kPa}$ compared to $\mathrm{LWP}_{\mathrm{p}}=-80 \mathrm{kPa}$ on T4).}

The difference in response rate between leaves (especially sunlit leaves) and bunches can probably be ascribed to different water capacities. Due to its smaller capacity, small losses of water in a leaf should lead to larger changes in water potential than that of bunches. The delayed decrease in water potential of bunches may also be due to an indirect pathway of water loss from the berries which are known to contain no stomata (Pratt, 1971). From the daily water potential changes in Fig. $1 \& 2$ it is clear that a water potential gradient

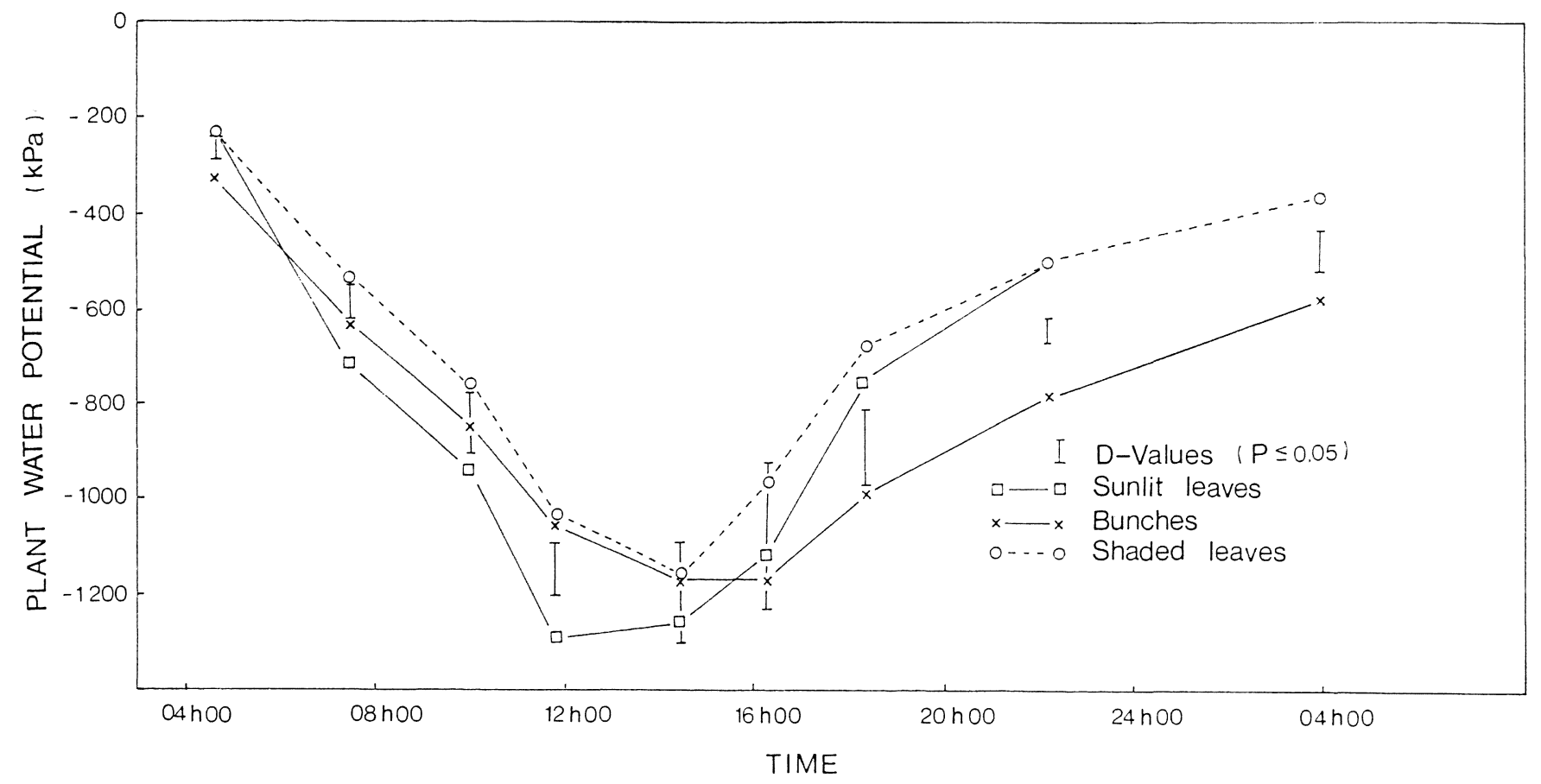

FIG. 2

Daily variation $(6 / 1 / 82)$ in the water potential of leaves and bunches of vines at a $25 \%$ soil water regime (T1). 
existed from approximately $08 \mathrm{~h} 00$ to $16 \mathrm{~h} 00$ between sunlit leaves and the bunches. Water would consequently flow from the bunches to the sunlit leaves. This driving force would not only lead to water loss from the bunches but also from other plant organs such as trunks, known for their diurnal shrinking and swelling in phase with gains and losses of water in the plant (Kozlowski, 1972). Depending on internal plant resistances to redistribution of water in the plant (not determined in this study), bunches would thus lose water via sunlit leaves. This mechanism could explain the delayed decrease of bunch water potential.

Recharging of plant water content takes place through root uptake. According to the above hypothesis, the bunches can be viewed as reservoirs which are filled by water extraction from the soil in the late afternoon and at night, and which supply water to the leaves and other tissue during part of the day. If true, the mechanism could explain to some extent why heavily cropped vines utilize more soil water than ones bearing less fruit. This latter phenomenon is well-known among farmers and was actually proved by soil sampling in the experimental vineyard (Table 1). In this comparative study the consumptive water use $(67,2 \mathrm{~mm})$ of vines with a crop load of $17,74 \mathrm{~kg}$ during a 27 day period in summer was significantly more than the water use $(52,9 \mathrm{~mm})$ of vines which bore only $8,97 \mathrm{~kg}$ of grapes. However, the effect of crop load on plant water requirements is normally explained by lower stomatal resistances in fruiting plants compared to non-fruiting plants (Hofäcker, 1976; Monselise \& Lenz, 1980). Loveys \& Kriedemann (1974) suggested that stomatal response is hormonally controlled in vines.

\section{TABLE 1}

Evapotranspiration of Colombar/99R bearing different crop loads (10/12/81-6/1/82).

\begin{tabular}{|c|c|}
\hline Crop Load (kg/vine) & Evapotranspiration $(\mathrm{mm})$ \\
\hline 17,74 & 67,2 \\
12,53 & 64,1 \\
8,97 & 52,9 \\
& LSD $(\mathrm{P} \leqslant 0,05)=11,2$ \\
\hline
\end{tabular}

\section{Diurnal patterns and water stress:}

For the ease of interpretation, results of only one typical measurement day $(4 / 2 / 82)$ in the drying cycle are presented in Figs. $3,4 \& 5$. At this stage the pre-dawn LWP of T8 (stressed plot) was already $-200 \mathrm{kPa}$ below that of both $\mathrm{T} 4$ and $\mathrm{T} 9$ vines (Fig. 3). This difference in LWP between T8 and the other two treatments due to water stress in the T8 vines, continued throughout the day and was reflected in the water potentials of both sunlit and shaded leaves. The higher LWP of shaded leaves in comparison with their sunlit counterparts is once more clearly illustrated in Fig. 3. Measurements of LWP showed water stress in T9 vines (compared to the control) at $14 \mathrm{~h} 00$ only.

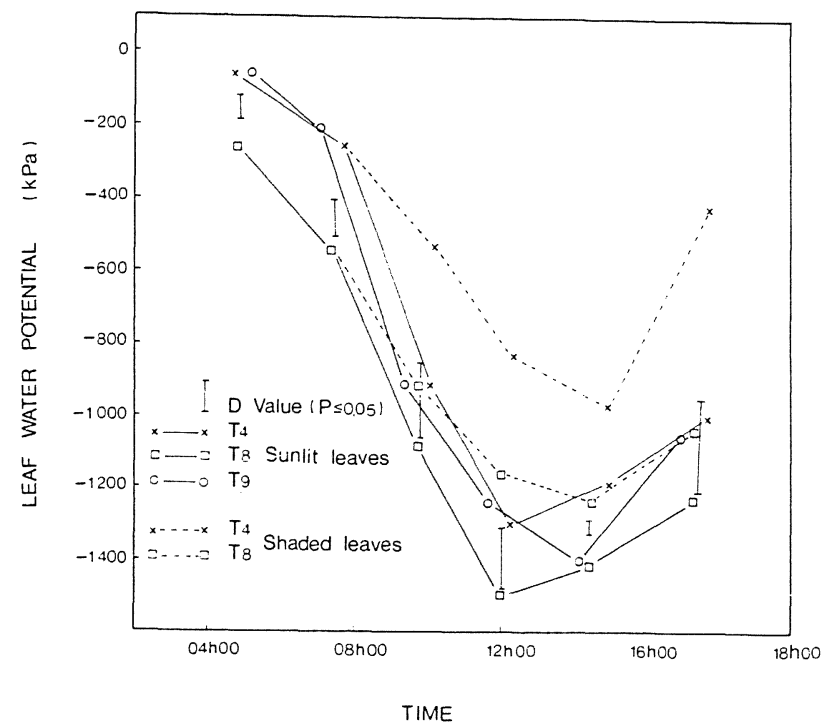

FIG. 3

Diurnal variation of leaf water potential in the experimental vineyard on the typical measurement day $(4 / 2 / 82)$.

On this measurement day LWP was correlated significantly with $\mathrm{T} l(\mathrm{r}=-0,95), \mathrm{PAR}(\mathrm{r}=-0,85), \mathrm{RH}(\mathrm{r}=$ $0,82)$ and even with wind $(r=-0,63)$ (Table 2$)$. Of all the variables, leaf temperature correlated best with LWP on most measurement days yielding a partial correlation coefficient of $\mathrm{R}=-0,90$ on average.

\section{TABLE 2}

Simple correlation coefficients ( $r$ ) between plant parameters of water stress and environmental factors in a Colombar/99R vineyard on a typical day (4/2/82).

\begin{tabular}{|ll|c|c|}
\hline Independent Variables & $\begin{array}{c}\text { Leaf Water } \\
\text { Potential } \\
(\mathrm{LWP})\end{array}$ & $\begin{array}{c}\text { Photo- } \\
\text { synthetic } \\
\text { Activity (PA) }\end{array}$ \\
\hline RH & $(\%)$ & $0,82^{* *}$ & $0,55^{*}$ \\
Wind & $\left(\mathrm{km} \mathrm{h}^{-1}\right)$ & $-0,63^{*}$ & 0,21 \\
PAR & $\left(\mu \mathrm{Es}^{-1} \mathrm{~cm}^{-2}\right)$ & $-0,85^{* *}$ & $0,74^{* *}$ \\
Tl & $\left({ }^{\circ} \mathrm{C}\right)$ & $-0,95^{* *}$ & $0,57^{*}$ \\
LWP & $(\mathrm{kPa})$ & - & $-0,53^{*}$ \\
Rs & $\left(\mathrm{s} \mathrm{cm}^{-1}\right)$ & $-0,09$ & $-0,62^{*}$ \\
\hline
\end{tabular}

* Significant $(\mathrm{P} \leqslant 0,05)$

** Highly Significant $(\mathrm{P} \leqslant 0,01)$

On the typical measurement day of $4 / 2 / 82$, stomatal resistance (Rs) for sunlit leaves decreased from the first reading of the day to assume low values (between 1,5 and $3,0 \mathrm{~s} \mathrm{~cm}^{-1}$ ) during the middle part of the day and increased again in the late afternoon $(17 \mathrm{~h} 00-18 \mathrm{~h} 00)$ for the two unstressed treatments T4 and T9 (Fig. 4). Stomata of T8 vines were already partly closed during the middle part of the day as could be seen from the gener- 
ally higher Rs values of this treatment in comparison with T4 and T9. Stomatal resistance of shaded leaves were always much higher than those of sunlit leaves, probably due to the poorer light conditions measured above the shaded leaves. Rapidly changing light conditions early in the morning (before $08 \mathrm{~h} 00$ ) were also responsible for differences in stomatal resistance at that stage. In general, stomatal resistance did not correlate well with the other measured parameters, the exception being 20/1/82 and 16/2/82 when PAR explained $45 \%$ and PAR + Tl explained $68 \%$ of the variation in Rs respectively (data not shown).

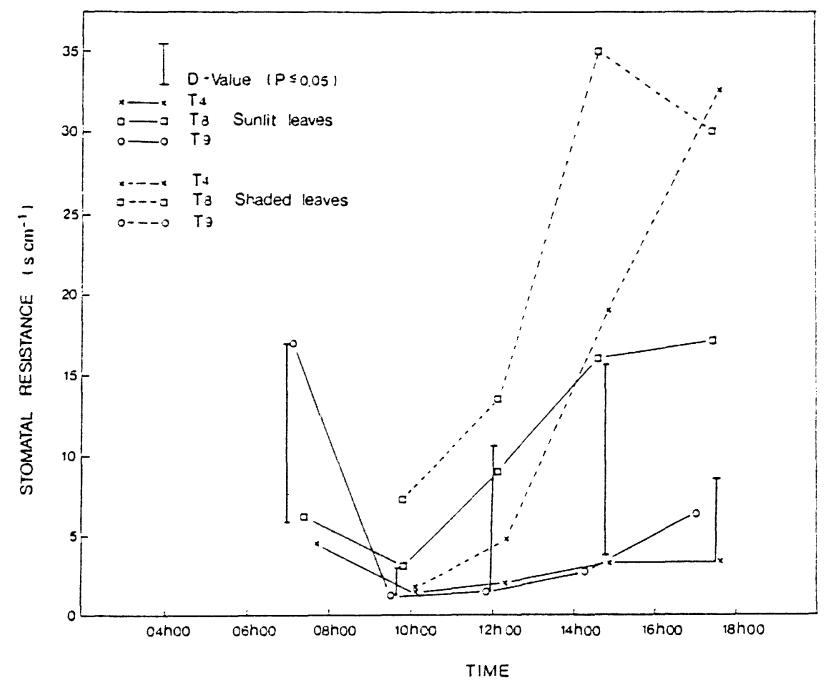

FIG. 4

Diurnal variation of stomatal resistance in the experimental vineyard on the typical measurement day $(4 / 2 / 82)$.

Photosynthetic activity (PA) for the stressed vines (T8) was significantly lower than for their unstressed counterparts (T4 and T9) between $10 \mathrm{~h} 00$ and $15 \mathrm{~h} 00$ on 4/2/82 (Fig. 5). Midday values for the unstressed vines varied from $70-83 \mathrm{mg} \mathrm{CO}_{2} \mathrm{dm}^{-2} \mathrm{~h}^{-1}$. On the typical day (4/2/82) PA correlated best with PAR $(r=0,74)$ (Table 2 ). Significant correlations were also found with all the other parameters except wind speed. Regression analysis showed that PAR could explain $50 \%$ of the variation in PA. An additional 14\% could be explained by Rs. When other measurement dates were also considered it became apparent that PAR was the predominant factor which controlled photosynthesis on most dates and could explain on average $43 \%$ of the variation in this plant parameter. On 8/2/82 when T8 had already been stressed severely, photosynthesis was best correlated with $\mathrm{Rs}(\mathrm{R}=-0,71)$.

\section{Onset of vine water stress:}

In order to eliminate the effect of climatological conditions on the plant parameters of water stress, the differences $(\triangle)$ between test (T8 and T9) and control (T4) values at the time of daily maximum stress, i.e. 14h00 15h00, were calculated. Differences of LWP and PA

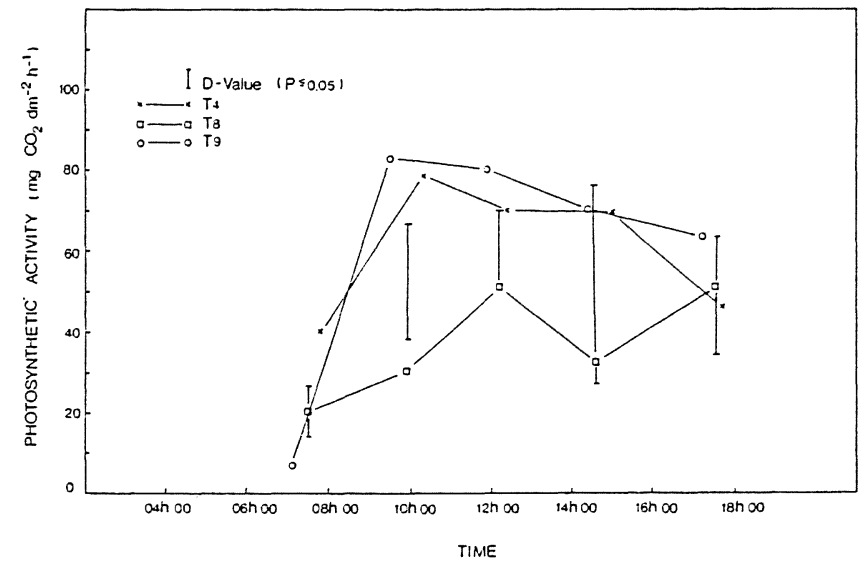

FIG. 5

Diurnal variation of photosynthetic activity in the experimental vineyard on the typical measurement day $(4 / 2 / 82)$.

were taken as control values minus test values while $\triangle$ Rs were obtained through subtraction of control values from test values. These differences were plotted against time to determine the onset of vine water stress (Fig. 6).

Treatment 9, which allowed soil water replenishment in the upper half of the soil profile only, at no stage showed a significant deviation from the control values as regards Rs or PA (Fig. 6). Pre-dawn LWP surpassed the control values from $28 / 1 / 82$, and $\mathrm{LWP}_{1+}$ did so on two dates (4/2/82 and 24/3/82) only. It therefore appeared as if T9 vines experienced very little stress despite a low water potential in part of its root zone.

T8 vines responded to the drying of the soil as regards the four plant parameter differences (Fig. 6). The pre-dawn LWP differences $(\triangle L W P$ ), became significant for the first time on 28/1/82 (Fig. 6). Onset of stress, as indicated by $\mathrm{LWP}_{\mathrm{p}}$ thus occurred between $20 / 1 / 82$ and $28 / 1 / 82$ and the stress continued till the end of the season.

Pre-dawn LWP correlated significantly with SWC $(r=0,89)$ and SWP $(r=0,95)$ (Table 3). The latter variable, being a fundamental property and in its effect independent of soil type, was in the present study preferred to SWC as an independent variable for regression analysis. Soil water potential explained $90 \%$ of the variation in $\mathrm{LWP}_{\mathrm{p}}$. Substitution of $\mathrm{Y}$ by $\operatorname{LWP}_{\mathrm{p}}(-316$ $\mathrm{kPa}$ at the detection of water stress on 28/1) in the regression equation $\left(\mathrm{Y}=-98,6541+3,3840 \mathrm{X}_{2}\right)$ obtained through stepwise regression analysis, indicated the onset of water stress at a SWP of $-64,2 \mathrm{kPa}$. The SWP value corresponded to a soil water level of $42 \%$.

Leaf water potentials at $14 \mathrm{~h} 00$ seemed to be a less sensitive indicator of vine water stress than the predawn values. Differences of $\operatorname{LWP}_{1+}\left(\triangle \mathrm{LWP}_{14}\right)$ started to increase on $28 / 1 / 82$, but this increase only became significant on 4/1/82 (Fig. 6). A number of soil, atmospheric and plant parameters correlated significantly with $\mathrm{LWP}_{14}$ (Table 4). The coefficient of determination $\mathrm{R}^{2}=0,70$ ) was highest for SWP. Addition of $\mathrm{RH}$ as an independent variable into the regression equation ac- 

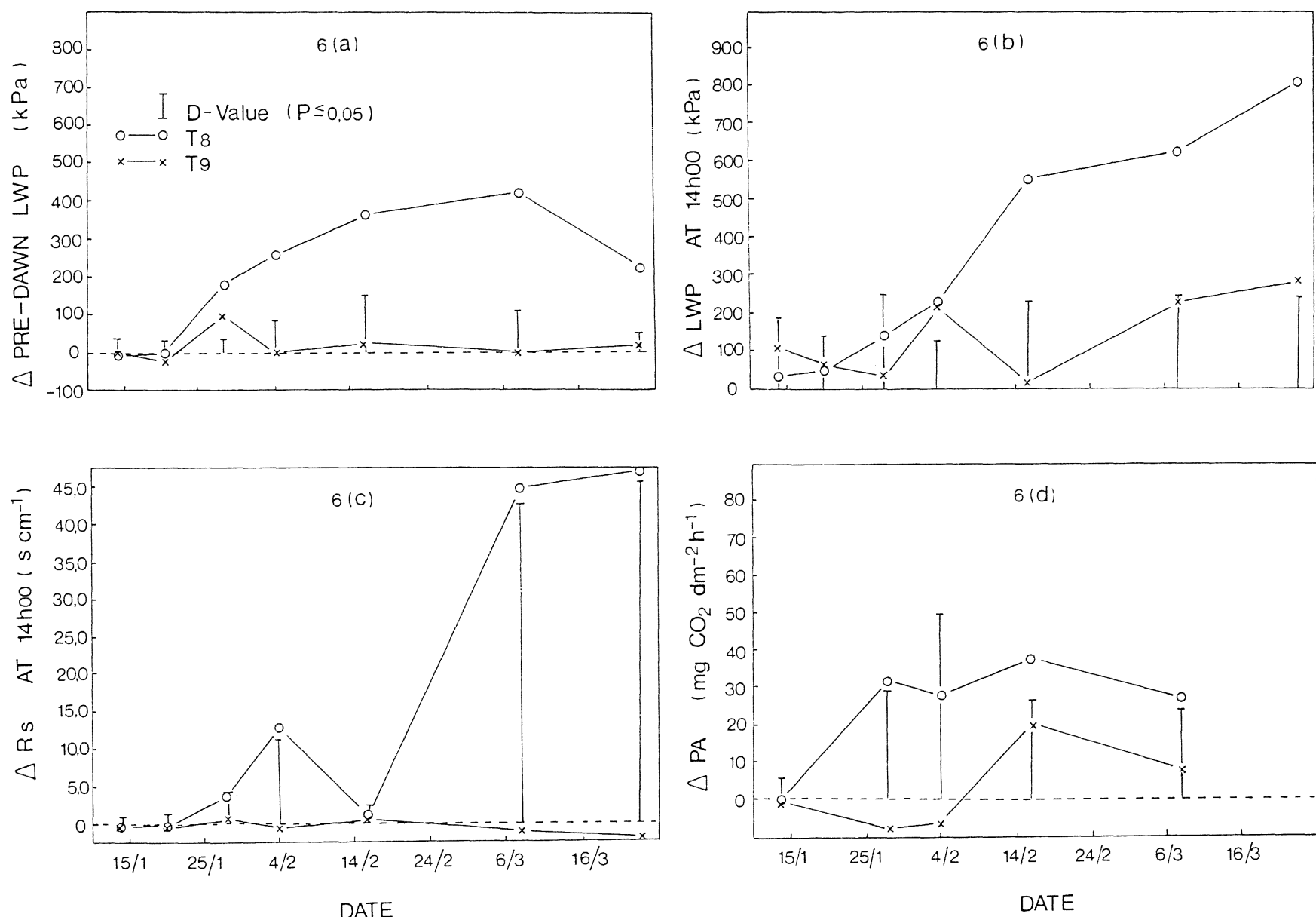

FIG. 6

Plant parameter differences $(\triangle)$ of two irrigation treatments compared to a well-watered control (T4) during the ripening stage of the experimental vineyard.

TABEL 3

Regression analysis of the relationships between pre-dawn LWP (dependent variable) and various environmental factors and plant parameters determined at $14 \mathrm{~h} 00$.

\begin{tabular}{|c|c|c|c|c|c|c|}
\hline \multicolumn{2}{|c|}{ Independent Variables } & Mean & $\begin{array}{c}\text { Standard } \\
\text { Deviation }\end{array}$ & $\mathrm{r}$ & $\mathrm{R}^{2}$ & $\begin{array}{c}\text { Regression } \\
\text { Equation }\end{array}$ \\
\hline $\begin{array}{l}\mathrm{X}_{1}=\mathrm{SWC} \\
\mathrm{X}_{2}=\mathrm{SWP}\end{array}$ & $\begin{array}{l}(\operatorname{Mass} \%) \\
(\mathrm{kPa})\end{array}$ & $\begin{array}{l}17,13 \\
-34,2\end{array}$ & $\begin{array}{l}4,10 \\
44,7\end{array}$ & $\begin{array}{l}0,89^{* *} \\
0,95^{* * *}\end{array}$ & \multirow[t]{6}{*}{0,90} & \multirow{6}{*}{$\begin{array}{c}Y=-98,6541 \\
+3,3840 X_{2}\end{array}$} \\
\hline $\mathrm{X}_{3}=\mathrm{RH}$ & $(\%)$ & 35,9 & 10,7 & 0,25 & & \\
\hline $\mathrm{X}_{+}=\mathrm{PAR}$ & $\left(\mu \mathrm{E} \mathrm{s}^{-1} \mathrm{~m}^{-2}\right)$ & 1153 & 485 & $-0,02$ & & \\
\hline $\mathrm{X}_{5}=\mathrm{T} l$ & $\left({ }^{\circ} \mathrm{C}\right)$ & 30,2 & 3,9 & $-0,09$ & & \\
\hline $\mathrm{X}_{6}=\mathrm{LWP}_{14}$ & $(\mathrm{kPa})$ & -1254 & 253 & $0,66^{* *}$ & & \\
\hline $\mathrm{X}_{7}=\mathrm{RS}$ & $\left(\mathrm{s} \mathrm{cm}^{-1}\right)$ & 43,29 & 32,2 & $-0,72^{* *}$ & & \\
\hline
\end{tabular}

* $\quad$ Significant $(P \leqslant 0,05)$

** Highly significant $(\mathrm{P} \leqslant 0,01)$

Regression equation was obtained with stepwise regression analysis: Addition of more independent variables in the equation gave no significant improvement of $\mathrm{R}^{2}$. 
TABEL 4

Regression analysis of the relationships between LWP at 14h00 (dependent variable) and various environmental factors and plant parameters determined at $14 \mathrm{~h} 00$.

\begin{tabular}{|c|c|c|c|c|c|c|}
\hline \multicolumn{2}{|c|}{ Independent Variables } & Mean & $\begin{array}{c}\text { Standard } \\
\text { Deviation }\end{array}$ & $r$ & $\mathrm{R}^{2}$ & $\begin{array}{l}\text { Regression } \\
\text { Equation }\end{array}$ \\
\hline $\mathrm{X}_{1}=\mathrm{SWC}$ & (Mass\%) & 17,05 & 3,71 & $0,63^{* *}$ & 0,56 & $\begin{array}{c}\mathrm{Y}=-2447,2766 \\
+49,3475 \mathrm{X}_{1} \\
+11,4182 \mathrm{X}_{3}\end{array}$ \\
\hline $\mathrm{X}_{2}=\mathrm{SWP}$ & $(\mathrm{kPa})$ & $-30,7$ & 39,6 & $0,71^{* *}$ & 0,70 & $\begin{aligned} Y & =-1463,6179 \\
& +5,2820 X_{2} \\
& +11,9882 X_{3}\end{aligned}$ \\
\hline $\mathrm{X}_{3}=\mathrm{RH}$ & $(\%)$ & 34,4 & 11,5 & $0,45^{*}$ & & \\
\hline $\begin{aligned} \mathrm{X}_{4} & =\mathrm{PAR} \\
\mathrm{X} & =\mathrm{T} l\end{aligned}$ & $\left(\mu \mathrm{E} \mathrm{s}^{-1} \mathrm{~m}^{-2}\right)$ & $\begin{array}{l}1188 \\
306\end{array}$ & $\begin{array}{l}448 \\
37\end{array}$ & $\begin{array}{l}-0,31 \\
-0,52 *\end{array}$ & & \\
\hline $\mathrm{X}_{6}=\mathrm{Rs}$ & $\left(\mathrm{s} \mathrm{cm}^{-1}\right)$ & 8,61 & 14,54 & $0,68^{* *}$ & 0,44 & $Y=-1098,7863$ \\
\hline $\mathrm{X}_{7}=\mathrm{LWP}_{\mathrm{p}}$ & $(\mathrm{kPa})$ & -200 & 141 & $0,65^{* *}$ & 0,72 & $\begin{array}{c}\mathrm{Y}=-1408,0157 \\
+14,5918 \mathrm{X}_{3} \\
+1,5339 \mathrm{X}_{7}\end{array}$ \\
\hline
\end{tabular}

* $\quad$ Significant $(P \leqslant 0,05)$

** Highly significant $(\mathrm{P} \leqslant 0,01)$

Regression equation was obtained with stepwise regression analysis: Addition of more independent variables in the equation gave no significant improvement of $\mathrm{R}^{2}$.

counted for an additional $23 \%$ of the variation in $\mathrm{LWP}_{14}$. Replacement of SWP and RH by LWP in the regression analysis, yielded $\mathrm{R}^{2}=0,39$ and after addition of $\mathrm{RH}$ as an additional independent variable into the regression equation, $72 \%$ of the variation in $\mathrm{LWP}_{14}$ could be explained. The high similarity between the $\mathrm{R}^{2}$ values obtained with either SWP and $\mathrm{LWP}_{\mathrm{p}}$ together with $\mathrm{RH}$ in the regression equation was to be expected when the good correlation $(r=0,95)$ between SWP and $\mathrm{LWP}_{\mathrm{p}}$ is considered.

The $\triangle$ Rs between T8 and T4 vines became statistically significant on $4 / 2 / 82$ (Fig. 6c). The low $\triangle$ Rs on the following measurement date, was possibly due to abnormal weather conditions on 16/2/82 (the RH was $55 \%$ at $14 \mathrm{~h} 00$ on this date compared to the normal 30 $40 \%$ during that time of day).

Although Rs correlated significantly with soil water status (SWC and SWP) and LWP both pre-dawn and at $14 \mathrm{~h} 00$, these correlations were not very good. The variation in $\mathrm{Rs}$ was best explained by $\mathrm{LWP}_{1+}\left(\mathrm{R}^{2}=0,44\right)$. However, combining other data sets obtained in the same vineyard with the present results revealed a much better relationship between Rs and LWP (Fig. 7). This data suggest that the stomata remained open with increasing LWP until a threshold value of approximately $-1600 \mathrm{kPa}$ was reached. Stomatal closure was rapid when this threshold LWP was exceeded. This value is higher than the threshold value of $-1300 \mathrm{kPa}$ reported for both potted and field grown Shiraz (Kriedemann \& Smart, 1971; Smart, 1974), or $-1000 \mathrm{kPa}$ found in a local study in a glasshouse (Van Zyl, 1984b). However, Liu et al. (1978) found stomatal closure of potted Concord at $-1300 \mathrm{kPa}$, but in a Concord vineyard the stomata remained open at $-1600 \mathrm{kPa}$. This variation among experimental results reconfirms the cautioning of Hsiao (1973) that plant adaptation to the environment could affect the water potential at which stress sets in.

The PA of T8 vines was already deleteriously affected by the soil water status on 28/1/82 as can be seen from the high PA difference ( $\triangle \mathrm{PA})$ (Fig. 6). Results of PA determinations on 20/1/82 were discarded due to instrument failure. It was consequently impossible to determine whether photosynthesis was affected even earlier in the drying cycle. Stomatal closure was clearly not the only factor responsible for the early decrease in photosynthetic activity since the Rs differential $(\triangle \mathrm{Rs})$

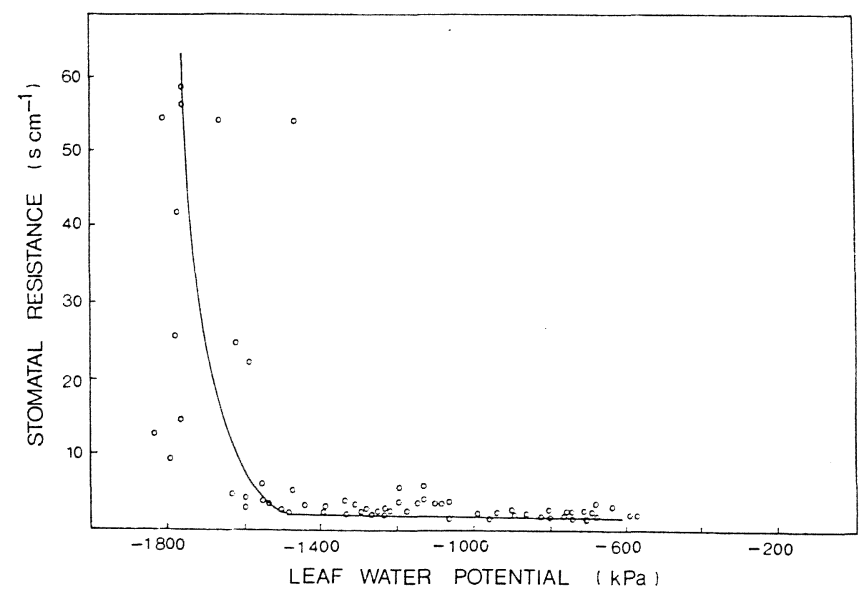

FIG. 7

Visual fitting to indicate the relationship between leaf water potential and stomatal resistance of sunlit leaves in the irrigation trial at Robertson. 
was only $3,5 \mathrm{~s} \mathrm{~cm}^{-1}$ at that stage. This finding supports the viewpoint that water stress not only causes stomatal closure and a consequent decline in $\mathrm{CO}_{2}$ uptake, but that it can also inhibit $\mathrm{CO}_{2}$ fixation through "injury".

\section{CONCLUSIONS}

Plant parameters, especially pre-dawn LWP, can detect the onset of water stress at an early stage. Due to their dependence on climatic factors these parameters fluctuate diurnally which complicates their direct application in practical irrigation scheduling. However, plant parameters proved to be ideal to calibrate instruments such as tensiometers for use on a farming level. The present study indicated the onset of water stress at a soil water potential of $-64 \mathrm{kPa}$ (average for the total rooting depth) which corresponded to a soil water level of $42 \%$ PAW.

Norms for LWP during ripening were also established. Water stress was signalled by a pre-dawn LWP of $-315 \mathrm{kPa}$. Further, stomata remained open until a threshold LWP of $-1600 \mathrm{kPa}$ was reached after which Rs values rose fairly rapidly. This threshold value of $-1600 \mathrm{kPa}$ was lower than the $-1300 \mathrm{kPa}$ reported by some researchers or the $-1000 \mathrm{kPa}$ found in local glasshouse studies, but should be viewed as a critical noontime LWP of Colombar under hot summer conditions.

Despite a large coefficient of variation $(\mathrm{cv}=39 \%)$ in PA data, there was a tendency for PA to decrease at the same early date at which $\mathrm{LWP}_{\mathrm{p}}$ indicated water stress. Photosynthesis, the basic process in plant production, may well prove to be a very sensitive indicator of water stress and should be included in future water stress experiments on grapevines.

The fact that vine water stress occurred at a fairly low soil water potential agrees with other research results which indicate that the grapevine can withstand a considerable amount of soil desiccation (onset of PAW at $42 \%$ soil water level) in the ripening period without crop loss. Furthermore, irrigation of only part of an extensive root zone did not result in water stress. This finding suggests that localised irrigation should be exploited more to reap the full benefits of water saving and reduced vegetative growth.

Heavily cropped vines had a higher water consumption than vines bearing a lighter crop. It is hypothesized that this yield/water consumption relationship is linked to water potential gradients between leaves and bunches. In this hypothetical model, bunches act as capacitors which gain and loose water depending on the time of day, eventually resulting in an increased soil water depletion rate. The occurrence of such water movement should, however, be investigated quantitatively in order to determine its magnitude and importance.

\section{LITERATURE CITED}

BEGG, J.E. \& TURNER, N.C., 1976. Crop water deficits. $A d v$. Agron. 28,161-217.

HILlEL, D., 1971. Soil and Water - Physical Principles and Processes. Academic Press, New York and London.

HOFÄCKER, W., 1976. Untersuchungen über den Einfluss wechselnder Bodenwasserversorgung auf die Photosyntheseintensität und den Diffusionswiderstand bei Rebblättern. Vitis 15, 171-182.

HOFÄCKER, W., 1977. Untersuchungen zur Stoffproduktion der Rebe unter dem Einfluss wechselnder Bodenwasserversorgung. Vitis 16,162.

HSIAO, T.C., 1973. Plant responses to water stress. Ann. Rev. Plant. Phys. 24, 519-570.

HSIAO, T.C., ACEVEDO, E., FERERES, E. \& HENDERSON, D.W., 1976. Stress metabolism. Water stress, growth and osmotic adjustment. Phil. Trans. R. Soc. London. B. 273, 479-500.

KASIMATIS, A.N., 1967. Grapes and berries. In: Hagen, R.M., Haise, H.R. \& Edminster, T.W. (eds.). Irrigation of agricultural lands. Agron. Series 11. Am. Soc. Agron., Madison Wisconsin, pp. 719-739.

KOZLOWSKI, T.T., 1972. Shrinking and swelling of plant tissues. In : Kozlowski, T.T., (ed.). Water deficits and plant growth III Academic press, New York, pp. 1-64.

KRAMER, P.J., 1983. Water relations of plants. Academic Press, New York.

KRIEDMANN, P.E. \& SMART, R.E., 1971. Effects of irridiance, temperature and leaf water potential on photosynthesis of vine leaves. Photosynthetica 5, 6-15.

LOVEYS, B.R. \& KRIEDEMANN, P.E., 1974. Internal control of stomatal physiology and photosynthesis. I. Stomatal regulation and associated changes in endigenous levels of abscisic and phaseic acids. Aust. J. Plant Physiol 1, 407-415.

LIU, W.T., POOL, R., WENKERT, W. \& KRIEDEMANN, P.E. 1978. Changes in Photosynthesis, stomatal resistance and abscisic acid of Vitis Labruscana through drought and irrigation cycles. Am. J. Enol. Vitic. 29, 239-246.

MONSELISE, S.P. \& LENZ, F., 1980. Effects of fruit load on stomatal resistance, specific leaf weight, and water content of apple leaves. Gartenbauwissenschaft 38, 109-115.

PRATT, C., 1971. Reproductive anatomy in cultivated grapes - A review. Am. J. Enol. Vitic. 22, 92-109.

SCHOLANDER, P.F., HAMMEL, H.T., BRADSTREET, E.D. \& HEMMINGSON, E. A., 1965. Sap pressure in vascular plants. Science 148, 339-346.

SHIMSHI, D., 1969. A rapid field method for measuring photosynthesis with labelled carbon dioxide. J. Exp. Bot. 20, 381-401.

SLAYTER, R.O., 1967. Plant water relationships. Academic Press, New York.

SMART, R.E., 1974. Aspects of water relations of the grapevine ( $V i-$ tis vinifera). Am. J. Enol. Vitic. 25, 84-91.

SMART, R.E. \& COOMBE, B.G., 1983. Water relations of grapevines. In : Kozlowski, T.T. (ed.). Water deficits and plant growth VII. Academic Press, New York, pp. 137-196.

VAN ZYL, J.L., 1984a. Response of Colombar grapevines to irrigation as regards quality aspects and growth. S. Afr. Enol. Vitic. 5, 19-28.

VAN ZYL, J.L., 1984b. Interrelationships among soil water regime, irrigation and water stress in the grapevine (Vitis vinifera L.). Ph.D. Dissertation, Univ. Stellenbosch, 7600 Stellenbosch, Rep. of South Africa.

VAN ZYL, J.L. \& WEBER, H.W., 1977. Irrigation of Chenin blanc in the Stellenbosch area within the framework of the climate-soilwater-plant continuum. Proc. Int. Symp. on the Quality of the Vintage. pp. 331-350. 14-21 Feb., Cape Town, South Africa. 